\title{
An Empirical Investigation of the Effect of Training and Development on Organizational Commitment in Higher Education Sector
}

\author{
Abd al-aziz Hamed Al-Refaei ${ }^{120}$ \\ Abdul Rahim Bin Zumrah ${ }^{3}$ \\ Mohsen Hasan Ali Bahaj ${ }^{24}$ \\ Ayman Saleh Alrefais
}

Faculty of Oil and Minerals, University of Aden, Yemen'

Shabwah University, Yemen ${ }^{2}$

Faculty of Leadership and Management, Islamic Science University of Malaysia

Seiyun Community College, Hadhramout, Yemen

Department of Education, the Islamic University, Saudi Arabia

\begin{abstract}
This study aims to empirically investigate the effect of training and development on the organisational commitment of employees in the context of higher education. The study adopts a quantitative research approach where data is collected using a self-administered survey questionnaire distributed among faculty staff of the Aden University in Yemen. A total of 296 usable responses were received. Data was analysis by confirmatory factor analysis (CFA) and structural equation modelling (SEM). The finding reveal a positive relationship between training and development, and organisational commitment. This study concludes that when organisations provide training and development to enhance the knowledge and skills of their employees, it will contribute towards employees extending greater effort into their commitment to that organisation.
\end{abstract}

Keywords: Training and development, organizational commitment, Higher Education, Social Exchange Theory

*Corresponding author: Abd Al-aziz Hamed Al-Refaei; Email: ah_alrefaei@yahoo.com DOI: https://doi.org/10.37227/JIBM-2021-09-1227

\section{Introduction}

Organisations in the higher education sector are depicted as being labour-intensive (Küskü, 2003; Refaei et al., 2019a). This is due to human factors playing a critical role in organisational success, where employees performed huge amount of the institution's resources and activities (Al-Refaei et al., 2019b). However, Higher education sector in Yemen facing a number of issues that led to limited contribution of higher education institutions to the development of the society (e.g., low of employees organizational commitment, employee dissatisfaction over the job assigned to them), consequences, low of academic staff performance as well as the institutional performance as whole, which have resulted in low of quality education (TSCEP, 2014; Al-refaei, 2021). Therefore, improving 
the higher education sector rests on the institution's ability to provide a conducive environment (Trivellas and Dargenidou, 2009) and an atmosphere in developing good relationships with employees.

Accordingly, developing such relationships can enhance the organisational commitment of their employees and their perception towards institutional practices, attitude, behaviour, and commitment, thereby improving productivity and performance (Al-Refaei et al., 2019a). Otherwise, as reflected in previous research, lack of employee commitment in higher education institutions (HEI) result in poor employee and organisational performance (Meyer et al., 1989; Muthanna, 2015). In this regard, organisations have recognised that, their ability to accomplish their aims and objectives dependent on employees' attitude and behaviour, when employees are dissatisfied or not committed or lack the willingness and motivation to exert additional effort to benefit the organisation, then organizations become disable to accomplish their aims and objectives (Zeithaml, Berry \& Parasuraman, 1996; AlRefaei et al., 2019b; Islam, Jantan, Khan, Rahman \& Monshi, 2018). Indeed, this also impacts higher education service quality that delivering to the customer (Al-Refaei et al., 2019a). Therefore, higher education institution use training and development programmes to enhance employee relationships, improve employee competence and maintenances and enhance employees' attitudes toward the organisation, such as organisational commitment.

However, the mechanisms explaining the effect of training and development on employee organisational commitment remain ambiguous. This situation can also be qualified to previous studies (e.g., Owoyemi et al., 2011; Kamau, 2015) where limited attention has been directed towards training and development programmes on organisational commitment given the unclear relationship and complications between them (Yang, Sanders, and Bumatay, 2012), and how employees perceive such programmes. Therefore, this study focuses on employees' perceptions of training and development and how these influences organisational commitment in higher education.

In both theory and practice, it has been recognised that training and development impact employee attitudes towards their respective organisation (e.g., Becker, 1993; Yang et al. 2012; Mathis et al., 2017; Armstrong \& Brown, 2019). The finding of the previous empirical studies validated the effect of training and development on organisational commitment (e.g., Yang et al., 2012; Bashir \& Long, 2015; Grund \& Titz, 2021; Choiriyah \& Riyanto, 2021). In contrast, other studies have shown negligible effects or, at best, a weak effect attributed to training and development on employee organisation commitment (e.g., Newman, Thanacoody, \& Hui, 2011). For instance, Cao \& Hamori found no direct effect of training and development on organisational commitment. Additionally, training had a negative insignificant moderate effect of support from senior management and organisational commitment.

Similarly, in another study, Rawashdeh and Tamimi (2019), using a sample of 302 nurses working in hospitals in Jordan, found a negative effect of perceived benefits of training towards organisational commitment. Other studies have also revealed the insignificant effect of training and development on components of organisational commitment. For example, Coffie, Boateng, \& Coffie (2021) discovered an insignificant effect of training and development on two of three components (continuance and normative) relating to organisational commitment. In contrast, Bashir and Long (2015) found a nonsignificant effect of training and development on continuance commitment. Contradictory with the result of previous studies regarding the effect of training and development on organisational commitment, further research is needed to investigate that relationship, 
particularly in the Middle East Region, since employee attitudes can differ from country to country and from region to region, given the diverse cultures.

\section{Training and Development}

Training and development are defined as an organisational procedure to enhance employee skills and knowledge development to achieve organisational goals. Training and development must contribute effectively to the satisfaction of the employee's personal goals (Nankervis, Baird, Coffey \& Shields, 2020). Organisations invest considerable time and money in training and development to improve employee performance and ultimately improve organisational performance (Nguyen \& Ngo, 2021). Moreover, training and development should be used as an effective and supportive strategy and mechanism towards the success of both the organisation and its employees (Okechukwu, 2017; Nguyen \& Ngo, 2021). The organisation's training and development efforts are critical to building employee competence and commitment (Mathis et al., 2017). Organisations typically use training and development as a learning process in providing meaningful learning opportunities for their employees (Bashir \& Long, 2015), aiming to develop employee's knowledge, skills, and abilities to perform their jobs more efficiently (Al-Refaei et al., 2019a; Al-Refaei et al., 2021).

Importantly, training and development together have been shown to improve organisational effectiveness (Ismael et al., 2021). Furthermore, organisations utilise training and development to create positive attitudes of their employees toward the organisation and improve their knowledge, skills, and abilities to perform current work practices successfully in achieving organisational aims and objectives. Employees perceived training and development by preparing them for growth opportunities in their future career and achieving positive personal results (e.g., more benefits, and high salary). Therefore, training and development can benefit both organisations and employees.

\section{Organizational Commitment}

Organisational commitment is defined as the relative strength of an individual's identification with and involvement in a particular organisation (Mowday et al., 1979; Meyer \& Allen, 1997). According to this definition, organisational commitment is the relationship and belief of employees with their organisation in corresponding to organisational goals and employee willingness to participate in the exchange of efforts in receiving benefits. Moreover, the employee desires to continue as a member of the organisation due to monetary considerations or having fewer options or alternatives elsewhere.

Meyer and Allen (1991) proposed the concept of a three-component model of organisational commitment, which remains the most popular model used in research (Chevalier et al., 2019). These components are affective commitment, continuance commitment, and normative commitment. Affective commitment refers to the emotional attachment of employees to the organisation, which can influence organisational performance (Meyer \& Allen, 1991; Pattnaik \& Sahoo, 2019; Machokoto, 2019). Employees will improve their emotional attachment to the organisation given they want to achieve their personal needs (social, physical, etc.) and goals (Mowday et al., 1979). Continuance commitment refers to a commitment based on the costs that an employee will incur if leaving the organisation or deciding to join another organisation (Meyer \& Allen, 1991; Alshanti, 2017; Pattnaik \& Sahoo, 2019). In other words, continuance commitment results from employees recognising possible losses (e.g., salary, seniority, promotions, other benefits) if 
deciding to leave the organisation. Normative commitment refers to the employee's feelings of the obligation to remain with the organisation or loyalty (Meyer \& Allen, 1991). It means that employees who remain in the organisation do so because they feel they should have a robust normative commitment.

\section{Theoretical Background and Previous Empirical Work}

Employees develop their commitment to their organisation based on the organisation's commitment towards them; when employees perceive that their organisation is committed to them, they are more likely to develop greater commitment to it (i.e., reciprocity) (Zagenczyk et al., 2020). When organisations provide employees with training and development, and employees reciprocate by showing more commitment, this could be explained through a social mechanism. According to Blau (1964), individuals tend to develop unspecified voluntary obligations in their social relationships; voluntary obligation occurs between two parties. When a person initiates doing a favour for another, he/she expects to receive something in return in the future (i.e., yield). However, the form of yield is based on the receiver's discretion in the future. According to Eisenberger et al. (2001), when an organisation values their employees' efforts and invests in delivering training and development programmes to improve their knowledge and skills, then employees will feel obligated to reciprocate (i.e., positive attitude and behaviour), such as through organisational commitment, to facilitate the achievement of organisational goals.

Training and development programmes offer a platform for employees to advance their skills and capabilities and provide them with opportunities for inclusion in the learning process and enhanced performance (Kirimi \& Maende, 2019). The effect of training and development on employee commitment is based on how employees perceive it. Suppose the employee views training and development as a gift from the organisation to develop their competence to perform the current job, and preparing for growth opportunities in their future career. In that case, employees will reciprocate by acquiring a positive attitude and behaviour (e.g., organisational commitment) based on the norm of reciprocity (Gouldner, 1960). Training and development play a critical role in creating positive social exchanges between an organisation and employees (Shen, \& Tang, 2018; Grund \&Titz, 2021; Al-Refaei, 2021). Regarding the effect of training and development and how it relates to organisational commitment through maintaining the relationship between employees and the organisation, Ganesan (2020) contended that when an organisation endeavours to provide employees with training and development to maintain a good relationship with their employees, employees will act positively via their attitude and behaviour. Hussain, Khan, and Khan (2020) mentioned that training and development could change employees' attitudes and behaviour towards their organisation. For instance, a change in employee attitude making them more committed to the respective organisation. Employee perception towards training and development in receiving support from their organisation increases their sense of reciprocity towards the organisation and increases their organisational commitment (Zagenczyk et al., 2020).

The theoretical aspect has been established in previous studies. For instance, in a sample gained from two organisations in the Philippines, Yang et al. (2012) found that employees' perception of training affected their commitment towards the organisation and gaining a positive result towards training on organisational commitment, related to benefit that employees receive from training and development (personal related benefits, careerrelated benefits, and job-related benefits). In addition, Ocen, Francis \& Angundaru (2017), employing a sample of 282 employees from the banking sector in Uganda, found that 
training effectively builds employee organisational commitment. Here, training creates a feeling of employees' emotional attachment to the organisation. They view training as a form of communication, revealing that the organisation has their interests at heart. Further, employees reciprocate by demonstrating more commitment and satisfaction. Grund \& Titz (2021) found that employees' participation in training positively and significantly affects their organisational commitment.

Based on this theoretical foundation and the findings of previous studies, this study expects that when employees perceive training and development in the form of support and gift from their organisation to develop their knowledge and skills in performing their job and preparing them for their future career and position, then employees will reciprocate by demonstrating more commitment to their organisation. Therefore, the following hypothesis is proposed:

Hypothesis: Training and development positively affect employees' organisational commitment.

\section{Methodology}

The objective of the current study aims to investigate the impact of training and development on employees' organisational commitment in the higher education sector. A quantitative approach was applied in this study as it allowed the researcher to make exact measurements of the variables, and test the hypothesis relevant data on the relationship between training and development and employees' organisational commitment (Sarstedt \& Mooi, 2019). A stratified random sample method was employed to collect data from the faculties at Aden University. A questionnaire was developed and distributed to the academic staff in the faculties. A total of 460 questionnaires were distributed, resulting in 296 valid responses received, a response rate of $64.34 \%$.

\section{Measures}

The training and development and employees' organisational commitment scales used in this study are commonly used for investigations related to human resource management. Some of the items used for scales training and development and organisational commitment measurements were modified to accommodate the university setting and goal and hypothesis of this study.

\section{Training and Development}

Five items developed by Bae and Lawler (2000) were used to measure training and development. However, Prieto-Pastor and Martin-Perez (2015) introduced the short scale, a sample of items. The university provides various forms of training and development for employees and has developed a good mentoring system to support new employees. This short scale has been widely used in previous studies, especially in the higher education context, regarding the effect of training and development on service quality delivered to customers (Al-Refaei et al., 2021). The measurement achieved an adequate reliability value $(a=.86)$.

\section{Organizational Commitment}

According to Meyer \& Allen (1991), organisational commitment consists of affective, continuance and normative commitment. The literature has shown that only affective and continuance commitment have a significant effect on employee performance. Another aspect of organisational commitment, known as normative, shows no effect on employee 
performance (Malhotra \& Mukherjee, 2003). Affective and continuance commitment effect the higher education service quality delivered by employees (Al-Refaei et al., 2019a). Therefore, organisational commitment in the context of the current study was measured using (8) items developed by Meyer and Allen (1991). Affective commitment was measured by (4 items), and continuance commitment was measured by (4 items). This scale has been employed widely in previous studies (Wang 2015; Al-Refaei et al., 2019a).

\section{Data Analysis and Result}

The data analysis process for this study was conducted in two stages. The first stage used SPSS v.26.0 for the descriptive statistics and reliability analysis. The second stage used AMOS v.26 for confirmatory factor analysis (CFA) to verify the fitness of the scales and to test the hypothesis via structural equation modelling (SEM). Some indexes were used for the assessment of the fitness of the model; index $\chi^{2}$ adjusted by degrees of freedom or relative $\chi^{2}\left(\chi^{2 / d f}\right)$, comparative fit index (CFI), Tucker-Lewis index (TLI), and root mean square error of approximation (RMSEA) were used to test the effect of training and development on employee's organisational commitment.

\section{Demographic Profile of Respondents}

Descriptive statistics by used SPSS v.26.0 expressed the profile of the participated in this study. Table 1 outlines the profile of the employees who participated in this study are 296 of the academic staff, $72.5 \%$ are males, and $27.5 \%$ are females. Regarding of age, $40.9 \%$ of the participating are below 40 years, and $59.1 \%$ are above 40 years. In term of qualifications, $29.7 \%$ of the participating employees hold a bachelor's degree, $19.9 \%$ hold a master's degree, and $50.3 \%$ are $\mathrm{PhD}$ holders. As for their working experience, $49 . \%$ of the respondents have been in this university for less than 10 years, and remain $51 . \%$ have been with this university for more than 10 years.

Table 1. Demographic Profiles of the Respondents

\begin{tabular}{cccc}
\hline Profile & Category & Frequency & Percentage (\%) \\
\hline \multirow{2}{*}{ Gander } & Male & 215 & 72.5 \\
\cline { 2 - 4 } & Female & 81 & 27.5 \\
\hline \multirow{2}{*}{ Age } & Below 40 years & 121 & 40.9 \\
\cline { 2 - 4 } & Above 40 years & 175 & 59.1 \\
\hline \multirow{2}{*}{ Experience } & less than 10 years & 145 & 49 \\
\cline { 2 - 4 } & more than 10 years & 151 & 51 \\
\hline \multirow{2}{*}{ Qualifications } & Bachelor's & 88 & 29.7 \\
\cline { 2 - 4 } & Master's & 59 & 19.9 \\
\cline { 2 - 4 } & PhD & 149 & 50.3 \\
\cline { 2 - 4 } & &
\end{tabular}

\section{Assessment of Measurement Model}

The proposed measurement model for the current study was constructed by two latent variables: training and development and organisational commitment of 23 observed variables. The factor loading estimates for all items were above the cut-off point; the loading ranged between 0.67 and 79 for training and development and between 0.75 and 0.90 for organisational commitment (see Table 2). The result of the CFA for the measurement model (see Figure 1) revealed acceptable model fit, where the $\chi 2$ statistic was $138.230, \mathrm{df}=62$ 
$(\mathrm{CMINDF}=2.230, \mathrm{p}<0.000), \mathrm{CFI}=0.957, \mathrm{TLI}=0.945$, and RMSEA $=0.065$. These indices showed an acceptable model fit (Hair et al. 2019).

Concerning the reliability and validity of the measurement model, all constructs' reliability was measured using composite reliability (CR). In contrast, convergent validity was measured by factor loadings for items and average variance extracted (AVE) for constructs. The reliability and convergent validity results showed acceptable indicators, as shown in Table (2).

Table (2) revealed that the factor loadings for all items included in the measurement model were higher than 0.60 (Awang, 2012; Hossain, Islam, and Haque, 2021). In contrast, the results of composite reliabilities of each construct showed high values, which (CR) were above the target threshold value of 0.70 as suggested by (Hair et al., 2019). The CR was 0.842 for training and development and 0.71 for organisational commitment, while the value of AVE for each construct was higher than 0.50 as recommended by (Hair et al., 2019). The value of AVE was 0.52 and 0.54 , which was below the value of CR. Accordingly, the convergent validity of the current measurement model was confirmed.

Table 2. Overall Reliability, Factor Loadings of Indicators and Validity of the all Constructs

\begin{tabular}{|c|c|c|c|c|}
\hline Construct and Indicators & Loading & $\overline{\mathbf{C R}}$ & $\overline{\mathrm{AVE}}$ & MSV \\
\hline \multicolumn{5}{|l|}{ Training and development } \\
\hline $\begin{array}{l}\text { Managers initiate and provide various kinds of } \\
\text { training and development for their employees. }\end{array}$ & .71 & & & \\
\hline $\begin{array}{l}\text { Employees will normally go through ongoing } \\
\text { training programmes. }\end{array}$ & .73 & & & \\
\hline $\begin{array}{l}\text { Our university has good mentoring system to } \\
\text { support new hires. }\end{array}$ & .79 & 0.842 & 0.52 & 0.139 \\
\hline $\begin{array}{l}\text { The university provides training focused on team- } \\
\text { building and teamwork skills training. }\end{array}$ & 69 & & & \\
\hline $\begin{array}{l}\text { Managers provide specialized training and } \\
\text { development for their employees. }\end{array}$ & 67 & & & \\
\hline \multicolumn{5}{|l|}{ Organizational commitment } \\
\hline \multicolumn{5}{|l|}{ Affective } \\
\hline I am very happy to be a member of this university & .80 & & & \\
\hline I feel great loyalty toward this university. & .85 & & & \\
\hline I would feel guilty if I left my organization now & .76 & & & \\
\hline I owe a great deal to my organization & .75 & & & \\
\hline \multicolumn{5}{|l|}{ Continuance } \\
\hline $\begin{array}{l}\text { Too much of my life would be disrupted if I } \\
\text { decided to leave my university right now. }\end{array}$ & .75 & 0.71 & 0.540 & 0.139 \\
\hline $\begin{array}{l}\text { It would be very hard for me to leave the university } \\
\text { right now, even if I wanted to. }\end{array}$ & .79 & & & \\
\hline $\begin{array}{l}\text { It would be too costly for me to leave my university } \\
\text { right now }\end{array}$ & .90 & & & \\
\hline $\begin{array}{l}\text { I would be spending the rest of my career in this } \\
\text { university }\end{array}$ & .75 & & & \\
\hline
\end{tabular}


Discriminant validity (DV) indicates the degree of distinct variables from each other (Hair et al., 2010). Thus, two approaches were adopted for this study to assess the DV of the measurement model. First, the Fornell Larcker criterion (FLC) was used (Fornell and Larcker, 1981). To assess DV using FLC, the square root of the AVE for all the constructs in the measurement model was employed and compared with the correlation values of the other constructs (Fornell and Larcker, 1981). Importantly, AVE square root coefficients in the correlation matrix should be higher than the value of squared correlation estimates of the construct to establish DV (Hair et al., 2019). Notably, the AVE square root values in this study exceeded the value of the correlation of all constructs. All diagonal elements in the correlation matrix were greater than the off-diagonal elements in the corresponding rows and columns, showing adequate DV of all the constructs as depicted in Panel A of Table (3).

The second approach was the Heterotrait-Monotrait Ratio (HTMT), as suggested by (Henseler et al., 2015). Even though FLC has been considered one of the most effective methods to assess DV, it failed to assess the lack of DV in some research situations. The HTMT is a new method proposed by Henseler et al. (2015) to assess DV; the value of HTMT of the constructs should be less than 0.85 (Henseler et al., 2015). Therefore, in the current study, the value of all constructs was less than 0.85, as recommended by Henseler et al. (2015). Hence, DV according to HTMT was established for all constructs, as shown in Panel $\mathrm{B}$ of the table 3 .

Table 3. Fornell-Larcker Criterion and Heterotrait-Monotrait ratio (HTMT)

\begin{tabular}{|c|c|c|c|c|}
\hline \multirow{2}{*}{ Variable } & \multicolumn{2}{|c|}{$\begin{array}{c}\text { Panel A: Fornell-Larcker } \\
\text { criterion }\end{array}$} & \multicolumn{2}{c|}{$\begin{array}{c}\text { Panel B: Heterotrait- } \\
\text { Monotrait ratio (HTMT) }\end{array}$} \\
\cline { 2 - 5 } & Training \&D & Commitment & Training \& D & Commitment \\
\hline Training and development & 0.719 & & & \\
\hline $\begin{array}{c}\text { Organizational } \\
\text { commitment }\end{array}$ & $0.372^{\cdots-}$ & 0.735 & 0.312 & \\
\hline
\end{tabular}

\section{Structural Model}

Structural equation model measure the proposed relationship between the variables, it tests the effect of training and development on organizational commitment (affective and continence). Model fit indices of the structure model show an acceptable fit, the $\chi 2$ statistic was 138.230, $\mathrm{df}=62$ (CMINDF $=2.23, \mathrm{p}<0.000), \mathrm{CFI}=0.957, \mathrm{TLI}=0.946, \mathrm{RMSEA}=0.065$. These indices showed acceptable model fit of this model according to (Hair et al, 2019). 


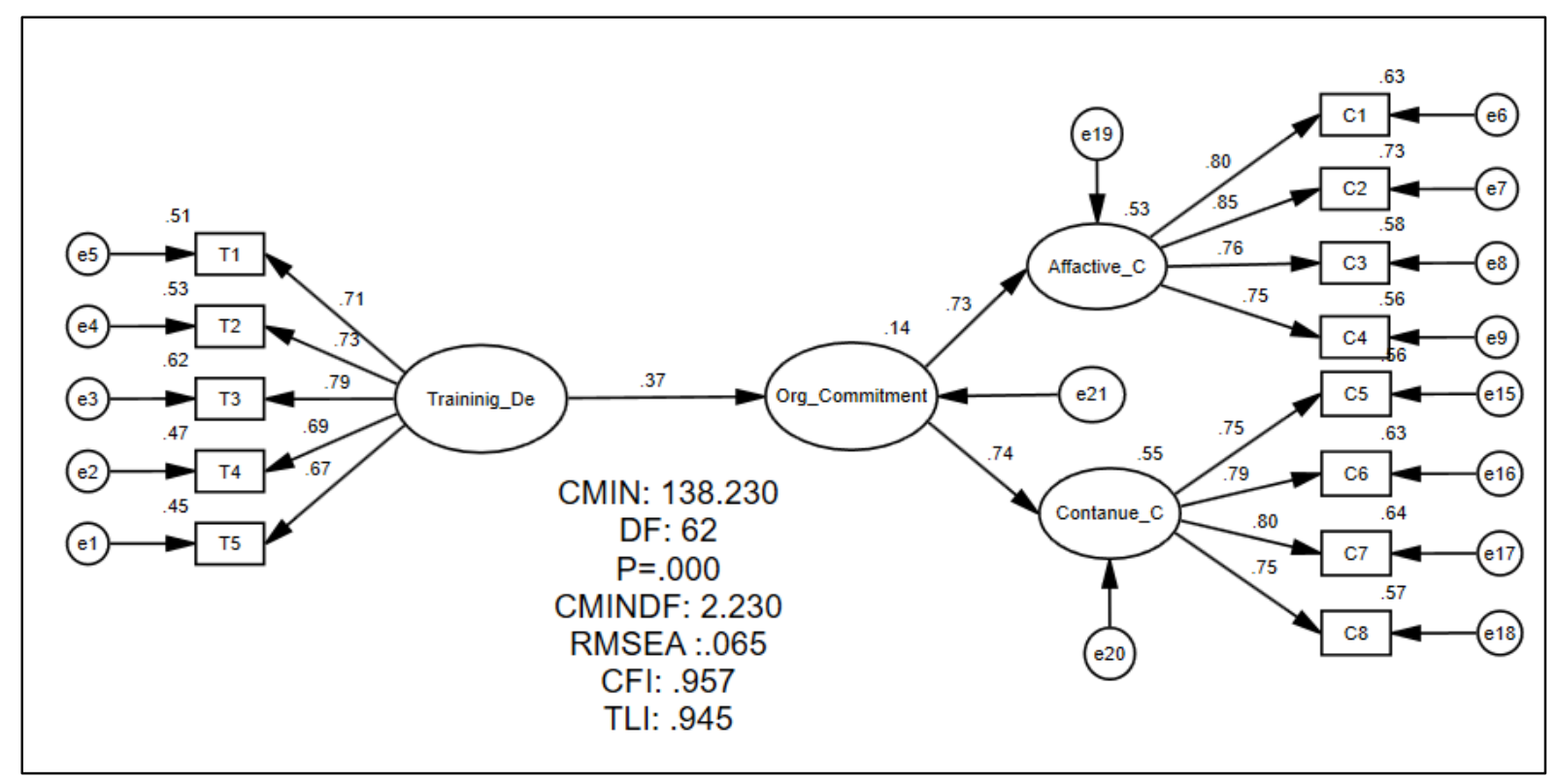

Figure 1. Structural equation model

The results of the structural model are presented in Table 4 that includes the value of Beta, which reflects the impact of the training and development as an independent variable on organisational commitment as a dependent variable; the Beta value reveals the direction of impact. In addition, the structural model provides the value of t-statistics and p-value, which measure the significance of the relationship. The cut-off point of t-statistics should be greater than 1.96, and the p-value should be less than 0.05, as suggested by (Byrne 2016). The results of the standardised regression estimation of the structural model are depicted in Table 4 below. Standardised path coefficients $\beta=.37, t=3.91, p=.000$ ). the results in the table support the hypothesis investigating the effect of training and development on organisational commitment.

Table 4. Standardized Regression Estimation

\begin{tabular}{|c|c|c|c|c|c|c|}
\hline & \multicolumn{2}{|c|}{ Estimate } & \multirow{2}{*}{$\begin{array}{c}\text { Standard } \\
\text { Error }\end{array}$} & \multirow{2}{*}{$\begin{array}{c}\text { t-value } \\
\text { (C.R) }\end{array}$} & \multirow[t]{2}{*}{ P Value } & \multirow{2}{*}{ Result } \\
\hline & USD & SD & & & & \\
\hline $\mathrm{T} \& \mathrm{D} \rightarrow \mathrm{OC}$ & 0.266 & 0.37 & 0.068 & 3.91 & 0.000 & Supported \\
\hline
\end{tabular}

*Note: $\mathrm{T} \& \mathrm{D}=$ Training and Development. $\mathrm{OC}=$ Organizational Commitment. USD= Unstandardized. SD= Standardised

\section{Discussion}

The objective of this study was to identify the effect of training and development on employees' organisational commitment in higher education. This study hypothesised that training and development have a positive significant effect on employees' organisational commitment. The findings of this hypothesis revealed that training and development has a positive and significant effect on employee's organisational commitment. The reason is that when employees perceive training and development as a gift from organisation to develop their competencies in performing their present job and preparing for growth opportunities in their future career, employees reciprocate by generating a positive organisational commitment based on the social exchange theory (Blau 1964), and the norm of reciprocity (Gouldner, 1960). Training and development play a critical role in creating a positive social exchange between an organisation and its employee. This result also demonstrates that when 
employees are offered training and development, consider this positively; the organisation has their interests at heart and well-being. Employees perceive this as a gift from the organisation and feel obligated to reciprocate by exerting effort to remain committed to that organisation.

Furthermore, it established that organisations can strengthen their relationship with employees by providing adequate training and development to enhance organisational commitment when the organisation provides training and development programmes to employees. Indeed, this will help to facilitate developing a good relationship between the organisation and employees. Employees will act through adopting a positive attitude and behaviour, such as organisational commitment. Also, because of the social mechanism, an organisation can ensure the commitment of employees, given that this is a critical factor for organisational effectiveness and success (Sharma, 2016; Ab Rahman \& Jantan, 2020). However, an organisation cannot achieve its goal when employees are noncommittal or unwilling to apply additional effort to benefit the organisation or contribute positively to achieve organisational goals and success (AL-Refaei et al., 2019b).

The results of this study are in line with the results of previous studies on the contexts of training and development and organisational commitment in higher education. Bashir \& Long (2015) investigated the effect of five training-related factors on organisational commitment in the higher education sector in Malaysia. They found that five training-related factors positively affect affective and normative commitment while no effect on continuance commitment. Similarly, a study by Okechukwu (2017) discovered a positive relationship between training and development and employee attitude (job satisfaction) in higher education in Malaysia.

Notably, this finding is consistent with the findings from previous studies by Yang et al. (2012), noting that employees' perception of training affected their commitment to the organisation. The positive result of training on organisational commitment was related to the benefit that employees receive from training and development. Similarly, Ocen et al. (2017) found a positive relationship between training and development and employee attitudes, discovering that training and development is a useful tool for building employees' organisational commitment directly and indirectly through job satisfaction. Likewise, Grund \& Titz (2021) found that employees' participation in training positively and significantly affects their organisational commitment.

\section{Implications of the study}

Despite the growing attention of impact of training and development to improve organizational commitment, most of previous studies conducted in developed countries such as America, Europe and different part of Asia (e.g. Bashir \& Long, 2015; Okechukwu, 2017; Chevalier et al, 2019; Choiriyah \& Riyanto, 2021). However, the finding of previous studies cannot be generalized to the other stage of economic such as least developed countries with cultural and national differences such as Yemen which characterized as poor economic growth (GSDRC, 2007). Therefore, this study adds to the previous discussion to verify the previous finding related to training and development and organizational commitment in the context of Yemen.

This study extends the existing literature by providing empirical evidence about mechanism that link training and development and organizational commitment. The link between variables (training and development on organizational commitment) were underpinned by social exchange theory. According to the theory, when employee received favourable treatment from their organization (in this study refer to training and 
development), they will feel obligated to return this treatment (be more committed). These findings were consistent with the social exchange theory. The academic staff at Aden University view training and development that being provided to them by their university as evidence that the university cares about developing their knowledge, skills and abilities to improve their performance for current job and future currier. As a result, the academic staff feel that it is their responsibility to reciprocate by showing a high level of commitment.

Practically, higher education institutions can improve organizational commitment of their employees through training and development. This study reveals that training and development at Aden University have a positive and significant effect on organizational commitment. The higher education institutions can control and enhance employee's organizational commitment by fording them with program of training and development to improve their knowledge, skills and abilities. Higher education institutions recognise that, having high-commitment academic staff will enable the university to educate better quality graduate and that will enhance competitive advantage of the university, its reputation, and market share as well as financial power.

\section{Limitations of the Study}

There are several limitations in this study. The first limitation concerns the data collection process, which is at a single point in time that adopts a cross-sectional design method. However, a longitudinal study would be better suited to investigate the effects of training and development on organisational commitment. The second limitation concerns the effect of training and development on organisational commitment. Future studies should consider other factors, such as job satisfaction as mediating the relationship between training and development and organisational commitment and the effects of training and development on employee attitudes and performance.

\section{Conclusion}

This study investigated the effects of training and development on employees' organisational commitment in the higher education context. Based on the social exchange theory, the results revealed a strong positive relationship between training and development and employees' organisational commitment. The study confirmed that when employees received training and development and support to enhance their skills and knowledge, and in their ability to perform their job better plus preparing them for future careers, employees reciprocate, feeling obligated through exerting further commitment towards the organisation. This result implies that HEI should actively employ training and development programmes to increase the commitment of employees, which can reduce employee turnover intention, contributing towards the achievement of organisational goals and objectives more efficiently.

\section{References}

Ab Rahman, M. R. Z. B., \& Jantan, A. H. B. (2020). Leadership Behavior Influence Organizational Commitment, Organizational Culture and Job Satisfaction at Public University in Malaysia. Journal of International Business and Management, 3(2), 01 13.

Al_Refaei, A. A. A. H., Ali, N. A. A. M. A., \& Bahaj, A. M. H. A. (2021). An Investigation on the Impact of Training and Development on Service Quality in the Higher Education Sector. Journal of Critical Reviews, 8(3), 250-260. doi: $10.31838 /$ jer.08.03.27 
Al-Refaei, A. H., Zumrah, A. \& Alshuhumi, S. (2019b). The Effect of Organizational Commitment on Higher Education Services Quality. E-Journal on Integration of Knowledge (7th edition).

Al-Refaei, A. H., Zumrah, A. B., Alsamawi, M. A., \& Alshuhumi, S. R. (2019a). A MultiGroup Analysis of the Effect of Organizational Commitment on Higher Education Services Quality. Journal of business society, 3(10), 40-48.

Al-refaei, A. H. (2021). The Relationship Between HRM Practices and Higher Education Service Quality in Yemen: Organizational Commitment, Job Satisfaction and Job Involvement as Mediating Variables. (Ph. D thesis). University Sains Islam Malaysia.

Alshanti, M. (2017). The relationship between Leadership patterns and Organizational Commitment: The Mediating Role of Job Satisfaction. Dar Almandumah, 2(7), 85-104.

Armstrong, M., \& Brown, D. (2019). Strategic Human Resource Management: Back to the future? A literature reviews. Institute for Employment Studies (IES) \& Chartered Institute of Personnel and Development (CIPD).

Bae, J., \& Lawler, J. J. (2000). Organizational and HRM Strategies in Korea: Impact on Firm Performance in an Emerging Economy. Academy of Management Journal, 43(3), 502-517.

Bashir, N., \& Long, C. S. (2015). The relationship between training and organizational commitment among academicians in Malaysia. Journal of Management Development. 34(10), 1227-1245.

Becker, G. (1993). Human capital: A theoretical and empirical analysis with special reference to education. Chicago, IL: University of Chicago Press.

Blau, P. M. (1964). Exchange and power in social life. New Brunswick.

Byrne, B.M. (2016). Structural equation modelling with AMOS: basic concepts, applications, and programming. Taylor and Francis.

Chevalier, S., Huart, I., Coillot, H., Odry, D., Mokounkolo, R., Gillet, N., \& Fouquereau, E. (2019). How to increase affective organizational commitment among new French police officers. The role of trainers and organizational identification. Police Practice and Research, 1-14.

Choiriyah, S., \& Riyanto, S. (2021). Effect of Training and Competence on Job Satisfaction and Its Impact on Employee Commitment (Case Study at BPJS Ketenagakerjaan). International Journal of Innovative Science and Research Technology. 6(6). 10211030.

Coffie, R. B., Boateng, K. A., \& Coffie, F. (2021). Organizational Commitment in HRM Practices: Insights from the Ghanaian Banking Industrial Experience. Insights into Economics and Management. 6, 125-142.

Eisenberger, R., Stinglhamber, F., Vandenberghe, C., Sucharski, I. L., \& Rhoades, L. (2001). Perceived Supervisor Support: Contributions to Perceived Organizational Support and Employee Retention. Journal of Applied Psychology, 87(3), 565.

Fornell, C., \& Larcker, D. F. (1981). Evaluating Structural Equation Models with Unobservable Variables and Measurement Error. Journal of Marketing Research, 18(1), 39-50.

Ganesan, M. (2020). Training and Its Impact on the Attitude of Employees of It Companies in Chennai. Journal of Critical Reviews, 7(1), 154-158.

Gouldner, A. W. (1960). The Norm of Reciprocity: A Preliminary Statement. American sociological review, 161-178.

Grund, C., \& Titz, K. (2021). Affective commitment through further training: the roles of firm provision and employee participation. Review of Managerial Science, 1-32. 
Hair, J., Black, W., Babin, B., and Anderson, R. (2010). Multivariate data analysis (7th ed.): Prentice-Hall, Inc. Upper Saddle River, NJ, USA.

Hair, J.F., Black. W.C., Babin. B.J., Anderson. R. E. (2019). Multivariate data analysis. (8 Ed). Cengage Learning EMEA.

Henseler, J., Ringle, C. M., \& Sarstedt, M. (2015). A new criterion for assessing discriminant validity in variance-based structural equation modeling. Journal of the academy of marketing science, 43(1), 115-135.

Hossain, M.S., Islam, M.A. and Haque, A.A. (2021). Empirical analysis to the factors impact on succession process of the family-owned businesses in Bangladesh, moderating role of education, International Journal of Business Innovation and Research, doi: 10.1504/IJBIR.2020.10032875.

Hussain, A., Khan, M. A., \& Khan, M. H. (2020). The Influence of Training and Development on Organizational Commitment of Academicians in Pakistan. Review of Economics and Development Studies, 6(1), 43-55.

Islam, M. A., Jantan, A. H., Khan, A. M., Rahman, M. H., \& Monshi, O. (2018). Impact of motivational factors on knowledge sharing behaviour of managers in Ready Made Garments (RMG) Industry of Bangladesh. Journal of Business and Retail Management Research, 13(1), 179-189.

Ismael, NB, Othman, BJ, Gardi, B., Hamza, PA, Sorguli, S., Aziz, HM, Ahmed, SA, Sabir, BY, Ali, BJ, Anwar, G.(2021). The Role of Training and Development on Organizational effectiveness. International Journal of Engineering, Business and Management, 5(3), 15-24.

Kamau, R. W. (2015). Factors influencing employee commitment and its impact on organizational performance: A case study of Kenya airports authority. (Doctoral dissertation, United States International University-Africa).

Kirimi, R. N., \& Maende, C. (2019). Training and Development Techniques and Employee Performance in the Ministry of Labour and Social Protection, Nairobi City County, Kenya. International Journal of Current Aspects, 3(2), 131-144.

Küskü, F. (2003). Employee satisfaction in higher education: the case of academic and administrative staff in Turkey. Career Development International, 8(7), 347-356.

Machokoto, W. (2019). The relationship between charismatic leadership and affective commitment: A systematic review. Journal of International Business and Management, 2(1), 1-11.

Malhotra, N., \& Mukherjee, A. (2003). Analysing the Commitment--Service Quality Relationship: A Comparative Study of Retail Banking Call Centres and Branches. Journal of Marketing Management, 19, 941-971.

Mathis, R. L., Jackson, J. H., Valentine, S. R., \& Meglich, P. A. (2017). Human Resource Management $15^{\text {th }}$ Ed.

Meyer, J. P., \& Allen, N. J. (1991). A three-component conceptualization of organizational commitment. Human Resource Management Review, 1(1), 61-89.

Meyer, J. P., \& Allen, N. J. (1997). Commitment in the Workplace: Theory, Research, and Application. Sage.

Meyer, J. P., Paunonen, S. V., Gellatly, I. R., Goffin, R. D., \& Et Al. (1989). Organizational commitment and job performance: It's the nature of the commitment that counts. Journal of Applied Psychology, 74(1), 152-156.

Mowday, R. T., Steers, R. M., \& Porter, L. W. (1979). The Measurement of Organizational Commitment. Journal of Vocational Behavior, 14(2), 224-247. 
Muthanna, A. (2015). Quality education improvement: Yemen and the problem of the 'brain drain'. Policy Futures in Education, 13(1), 141-148.

Nankervis, A., Baird, M., Coffey, J., \& Shields, J. (2019). Human resource management. 10 ed, Cengage AU.

Newman, A., Thanacoody, R., \& Hui, W. (2011). The impact of employee perceptions of training on organizational commitment and turnover intentions: a study of multinationals in the Chinese service sector. The International Journal of Human Resource Management, 22(8), 1765-1787.

Nguyen, M. H., \& Ngo, K. H. (2021). Evaluating the Effectiveness of Internal Training of Commercial Banks in Vietnam. International Journal of Education and Knowledge Management (IJEKM) 4(5): 1-14

Ocen, E., Francis, K., \& Angundaru, G. (2017). The role of training in building employee commitment: the mediating effect of job satisfaction. European Journal of Training and Development.

Okechukwu, W. (2017). Influence of Training and Development, Employee Performance on Job Satisfaction among the Staff. Journal of Technology Management and Business, 4(1).

Owoyemi, O., Oyelere, M., Elegbede, T., \& Gbajumo-Sheriff, M. (2011). Enhancing employees' commitment to organisation through training. International Journal of Business and Management, 6(7), 280-286.

Pattnaik, S. C., \& Sahoo, R. (2019). High-performance Work Practices, Affective Commitment of Employees and Organizational Performance : A Multi-level Modelling Using 2-1-2 Mediation Analysis. Global Business Review, 1-16.

Prieto-Pastor, I., \& Martin-Perez, V. (2015). Does HRM Generate Ambidextrous Employees for Ambidextrous Learning? The Moderating Role of Management Support. The International Journal of Human Resource Management, 26(5), 589-615.

Rawashdeh, A. M., \& Tamimi, S. A. (2019). The impact of employee perceptions of training on organizational commitment and turnover intention: An empirical study of nurses in Jordanian hospitals. European Journal of Training and Development. 44(2/3), 191207.

Sarstedt, M., \& Mooi, E. (2019). A Concise Guide to Market Research: The Process, Data, and Methods Using IBM SPSS Statistics (third edit). Springer.

Sharma, D. (2016). Organizational Commitment and Organizational Effectiveness. Clear International Journal Of Research In Commerce \& Management, 7(1).

Shen, J., \& Tang, C. (2018). How does training improve customer service quality? The roles of transfer of training and job satisfaction. European Management Journal, 36(6), 708716.

The Supreme Council of Education Planning TSCEP. (2014). Educational Indicators of the Republic of Yemen, Stages and Various 2012/2013. Prime Ministry, The Supreme Council of Education Planning TSCEP.

Trivellas, P., \& Dargenidou, D. (2009). Organisational Culture, Job Satisfaction and Higher Education Service Quality. The TQM Journal, 21(4), 382-399.

Wang, Y. (2015). Examining organizational citizenship behavior of Japanese employees: A multidimensional analysis of the relationship to organizational commitment. The International Journal of Human Resource Management, 26(4), 425-444.

Yang, H., Sanders, K., \& Bumatay, C. P. (2012). Linking perceptions of training with organizational commitment: The moderating role of self-construals. European Journal of Work and Organizational Psychology, 21(1), 125-149. 
Zagenczyk, T. J., Purvis, R. L., Cruz, K. S., Thoroughgood, C. N., \& Sawyer, K. B. (2020). Context and social exchange: perceived ethical climate strengthens the relationships between perceived organizational support and organizational identification and commitment. The International Journal of Human Resource Management, 1-20.

Zeithaml, V. A., Berry, L. L., \& Parasuraman, A. (1996). The behavioral consequences of service quality. Journal of Marketing, 60(2), 31-46. 